\title{
Evidence of Urban-Induced Precipitation Variability in Arid Climate Regimes
}

\author{
J. Marshall Shepherd \\ NASA/GSFC
}

\author{
Submitted to Journal of Arid Environments \\ May 2005
}

Corresponding Author:

Dr. J. Marshall Shepherd

Official and Permanent Address:

NASA Goddard Space Flight Center

Code 613.3

Greenbelt, MD 20771

Email: marshall.shepherd@nasa.gov

V: (301) 614-6327

F: (301) 614-5492

\begin{abstract}
The study employs a 108-year precipitation historical data record, global climate observing network observations and satellite data to identify possible anomalies in rainfall in and around two major arid urban areas, Phoenix, Arizona and Riyadh, Saudi Arabia. The analysis reveals that during the monsoon season, locations in northeastern suburbs and exurbs of the Phoenix metropolitan area have experienced statistically significant increases in mean precipitation of 12 to 14 percent from a pre-urban (1895-1949) to post-urban (1950-2003) period. Further analysis of satellite-based rainfall rates suggests the existence of the anomaly region over a seven-year period. The anomaly cannot simply be attributed to maximum topographic relief and is hypothesized to be related to urban-topographic interactions and possibly irrigation moisture. Temperature records suggest that Riyadh has experienced an adjustment in mean temperature in response to the growth of urban surfaces (e.g., the so-called urban heat island effect). While ground-based precipitation records also indicate an upward trend in mean and total precipitation in and around Riyadh in the last 10-15 years, it is difficult to attribute the increase to urbanization because other less urbanized stations in Saudi Arabia also show a similar increase. Recent satellite-based precipitation estimates indicate an anomaly region 50-100 km north of Riyadh, but this study is not robust enough to conclusively link it to urbanization although certain climate-regime attributes suggests that it might be.
\end{abstract}

Keywords: urban, precipitation, climate, Phoenix, Middle East, anthropogenic 


\section{Introduction}

Water is essential to life in the Earth system. The water cycle components that sustain life are becoming more scarce and polluted. The most recent (1999-2004) drought experienced in the southwestern United States is the seventh worst in the approximately 500-year proxy tree-ring record (Piechota et al. 2004). As a result, many regions contemplated "drought emergencies" in which severe water restrictions are implemented. Though largescale forcing likely controls drought processes (Hidalgo 2004), there is increasing evidence that anthropogenic or "human-related" activities can significantly alter precipitation processes. Urbanization is an example of anthropogenic forcing. Recent studies (Inoue and Kimura 2004; Burian and Shepherd 2004; Molders and Olson 2004; Dixon and Mote 2003; Shepherd and Burian; Bornstein and Lin 2000) continue to provide evidence that urban environments can modify or induce precipitation under a specific set of conditions. Results of these recent studies are consistent with previous historical work in this research area (Changnon et al. 1981; Huff 1986).

Arid and semi-arid regions of the southwestern United States and other parts of the world are rapidly developing and placing greater demands on the environmental system. In the past fifty years, Phoenix has expanded from a predominantly agricultural center to an urbanized region with extent 700 percent larger than its size in the middle of the twentieth century (Rex 2000). Riyadh's population grew from about a half million people in 1972 to almost two million by 2000 . Saudi Arabia experienced urbanization later than many other countries; in the early 1970s its urban-rural ratio was still about 1:3. By 1990 the ratio had reversed to about 3:1. In the mid-1970s Riyadh's population was increasing by about 10 percent a year. Irrigation also significantly increased between 1972 and 1990 (Metz 1993) southeast of Riyadh.

Figure 1 is a LANDSAT image depicting the rapid growth of Phoenix over the past few decades. Figure 2 is a combined LANDSAT and ASTER (Advanced Spaceborne Thermal Emission and Reflection Radiometer) image depicting the rapid urban growth of Riyadh, Saudi Arabia. ASTER is an imaging instrument flying on Terra, a satellite launched in December 1999 as part of NASA's Earth Observing System (EOS). There are a sampling of studies that discuss the anthropogenic impacts on the environment in arid regimes such as Kuwait City, Kuwait (Akber et al. 2001), Riyadh, Saudi Arabia (e.g., El-Sharif 1985; Modaihsh 1997), and Tehran, Iran (Karamouz et al. 2001). Additional localized impacts resulting from urban and agricultural development have been documented, including the modification of local climates (e.g., Qureshi and Khan 1994). 
However, there have been relatively few studies that focus on arid urban areas and precipitation enhancement. Balling and Brazel (1987) observed more frequent late afternoon storms in Phoenix during recent years of explosive population growth. Diem and Brown (2003) (hereafter DB03) suggested that anthropogenic activities in the Phoenix area affect summer precipitation totals, particularly the Lower Verde basin zone. Because arid regions lack substantial rainfall, investigators have not focused on these regimes for study of precipitation variability linked to human activity. Yet, they offer very unique attributes that are ideal for studying the problem. First, many areas in arid regimes have undergone rapid growth in the last 20-30 years which enables assessment of pre- and post- urban growth and precipitation data using a wealth of robust ground and satellite data sources. Second, the aridity of Phoenix and Riyadh minimizes the risk of precipitation contaminants from large-scale weather forcing such as fronts or low pressure systems thereby enabling a focus on convective-regional scale process linked to urbanization. Third, arid cities rely heavily on irrigation to support human activity. Increased irrigation could lead to moister environments to support or enhance precipitation processes.

\section{Science Objectives, Materials, and Methodology}

\section{a. Phoenix Study}

We chose the cities of Phoenix, Arizona and Riyadh, Saudia Arabia for the study for the aforementioned reasons. The methodology for each city differs because of data availability. DB03 offered very compelling findings but their study only investigated the relative increases in precipitation totals for a sample of stations in the basins east of Phoenix and only utilized precipitation data from 1950 to 2000 , which is essentially the post-urban period. Herein, urban processes are defined as including urban land use, urban aerosols, and human irrigation procedures. Our work extends DB03 in several important ways.

First, we utilize a high-quality, topographically-sensitive, 108-year precipitation data record provided by the Spatial Climate Analysis Service (SCAS) at Oregon State University. This 4-km resolution dataset resolves the preurban (1895-1949) and post-urban precipitation climatology for the southwestern U.S. This capability is necessary for detecting pre-urban and post-urban effects since the city cannot be physical removed for experimentation. PRISM (Parameter-Regression Independent Slopes Model) (Daly et al. 2002) is used to spatially distribute groundbased observations. The primary sources of observations currently used by SCAS for mapping precipitation are: 1) COOP (NWS COOPerative observations), 2) SNOTEL (USDA NRCS SNOw TELemetry), and 3) ASOS (NWS/FAA Automated Surface Observing System). The total number of precipitation stations was approximately 
12600 (figure 2). A particularly attractive feature of PRISM for studying mountainous regions is its ability to calculate linear climate-elevation relationships.

Second, we investigate the relative magnitude of mean precipitation totals in Phoenix and immediate surrounding regions. The goal is to verify results presented by DB03 that indicated a tendency for elevated precipitation totals in the Lower Verde basin region. We extend DB03 by integrating analysis of stations in the western and northern surrounding area as well as the Phoenix urban area. Statistical significance tests were conducted for the pre- and post-urban analyses and the relative magnitude analysis.

The experimental Tropical Rainfall Measuring Mission (TRMM) 3B42 real-time rainfall product (TRP, version 5) is used to examine mean rainfall rates of the central Arizona region during the extreme drought conditions of 2003. The goal is to detect the precipitation anomaly under relatively homogeneous drought conditions. TRP provides rainfall rate and accumulation estimates at $0.25^{\circ}$-resolution every three hours over the latitudinal range of $60^{\circ} \mathrm{N}-60^{\circ} \mathrm{S}$. TRP is a merger of all available SSM/I and TRMM microwave imager precipitation retrievals into a "high-quality" (HQ) precipitation estimate. The product also included precipitation estimates from geostationary infrared observations that are calibrated by the HP precipitation estimate (Huffman et al. 2003). Satellite data is useful because quantitative analysis of WSR-88D radar data is limited in terrain-intensive regions around Phoenix.

\section{b. Riyadh Study}

For this component of the study, we use data from the Global Climate Observing System (GCOS) Surface Network (GSN) and previously published data from Alkolibi (2002). The Global Climate Observing System (GCOS) was established in 1992 to ensure that the observations and information needed to address climate-related issues are obtained and made available to all potential users. It is co-sponsored by the World Meteorological Organization ( $\underline{\mathrm{WMO}})$, the Intergovernmental Oceanographic Commission (IOC) of UNESCO, the United Nations Environment Programme ( $\underline{\mathrm{UNEP}})$ and the International Council for Science (ICSU) . GCOS is intended to be a longterm, user-driven operational system capable of providing the comprehensive observations required for monitoring the climate system, for detecting and attributing climate change, for assessing the impacts of climate variability and change, and for supporting research toward improved understanding, modeling and prediction of the climate system. It addresses the total climate system including physical, chemical and biological properties, and atmospheric, oceanic, hydrologic, cryospheric and terrestrial processes. The National Oceanic and Atmospheric Administration's (NOAA) National Climatic Data Center (NCDC) is responsible for building a permanent data base of historical 
GSN daily and monthly data submissions, along with the appropriate station metadata history, and for providing free and open user access to this information via the World Wide Web. Our access point for the data was http://www.ncdc.noaa.gov/oa/climate/gsn/gsninfo.html. The study also employs data from version 6 of the TRMM 3B43 algorithm. The purpose of Algorithm 3B-43 is to produce the "Tropical Rainfall Measuring Mission (TRMM) and Other Data" best-estimate precipitation rate and root-mean-square (RMS) precipitation-error estimates. These gridded estimates are on a calendar month temporal resolution and a 0.25 -degree by 0.25 -degree spatial resolution global band extending from 50 degrees South to 50 degrees North latitude. The global rainfall algorithm (3B-43) combines the estimates generated by combined instrument rain calibration (3B-42) and global gridded rain gauge data from NOAA's Climate Prediction Center and/or global rain gauge product, produced by the Global Precipitation Climatology Center (GPCC). For more details of the algorithm, go to http/trmm.gsfc.nasa.gov/3b43.html.

The approach is to identify, using historical gauge data, any trends in temperature and precipitation in and around Riyadh and other Saudi Arabian stations in the GSN. Then, using the TRMM-based product, identify possibly precipitation anomalies that may be linked to the urbanized Riyadh environment.

\section{c. Climatology and Topography}

\section{i. Phoenix}

The southwest monsoon influence is greatest over portions of Mexico and extends into southeastern Arizona where average precipitation during July, August, and September exceeds $50 \%$ of the mean annual total. The Phoenix metropolitan area receives approximately $40 \%$ of its mean annual rainfall during the monsoon period. During the monsoon period, near-surface moisture availability in the Phoenix region peaks. The mean Tucson sounding (Wallace et al. 1999) in figure 3 indicates that on active monsoon days, the low-middle tropospheric flow is southeasterly. During the monsoon period, thunderstorms are an almost daily occurrence in the region. The large spatial variability of deep convection over Arizona (López et al. 1997) is directly related to the highly complex terrain of the state. Orographic effects tend to produce greater summer precipitation totals in the mountainous areas north and east of city (figure 4). In the early afternoon, convective activity peaks on the Mogollon Rim (Watson et al. 1994b). What is most interesting about the northeast Phoenix region is the apparent existence of an anomaly region (AR) where precipitation totals in the last 50 years appear to be greater than surrounding areas with similar or greater topographic relief. 


\section{ii. Riyadh}

Almost all of Saudi Arabia consists of semi-desert and desert with oases, where half of the total surface is uninhabitable desert. Most of the western parts of Saudi Arabia is plateau, the east is lowland, with very hot climate. The southwest has mountains as high as $3000 \mathrm{~m}$. Saudi Arabia, one of the driest and hottest countries in the world, is roughly located between north latitudes 17 and 31 and east longitudes 37 and 56. Except for the southwestern mountains, the average annual precipitation in the Kingdom ranges from $80 \mathrm{~mm}$ to $140 \mathrm{~mm}$ (Alkolibi, 2002). Maximum summer temperatures often exceed 45 degrees Celsius, relative humidity is very low and skies are clear most of the time. There is very little precipitation in Saudi's middle (the area known as the Rub Al-Khali desert, or the "empty quarter"). But, there is typically more precipitation in the highland and mountainous areas of the country. Precipitation increases southwest of the country in the Atlas mountains, as well as to the northeast in the Zagros mountains.

\section{Results}

\section{a. Phoenix}

\section{i. Analysis of Pre-Urban and Post-Urban Rainfall in the Phoenix Area}

The pre-urban (1895-1949) and post-urban (1950-2003) precipitation data were grouped such that the mean precipitation totals for the monsoon period (July-September) are aggregated. Table 1 summarizes the data for selected sites identified in figure 4. Sites were selected to represent the Phoenix region and selected sites to the southwest, northwest, northeast, and southeast of the urban area. We analyzed the time series of mean monsoon season precipitation for each site to determine if any significant differences between the pre-urban and post-urban period were evident.

Stations located southeast of the Phoenix area like Clifton and Duncan receive a significant amount of the precipitation during the monsoon period. Since synoptic-scale monsoon system should cause significantly higher precipitation totals in the monsoon zone than in regions around the Phoenix area, comparisons between moderately monsoon-impacted stations (i.e. Lower Verde) and strongly monsoon-impacted stations (i.e. "monsoon zone") enable a compelling examination of possible urban-induced increases in summer precipitation totals in the Lower Verde or northeast Phoenix region (DB03). The monsoon zone stations are above $1100 \mathrm{~m}$ above sea level. The Sunflower station, located in the Lower Verde basin northeast of Phoenix is also at significant elevation ( $>1100 \mathrm{~m})$ and is the wettest location in our sample. 
The most interesting result is how the mean precipitation amounts have changed from the pre-urban to posturban periods. Paired t-testing reveal that differences in pre-urban and post-urban precipitation mean totals are statistically significant at the $95 \%$ level. Regardless of monsoon region or topography, our results identify a preferred region of enhanced precipitation in the Lower Verde basin 30-50 km northeast of the Phoenix metropolitan area. The only stations in table 1 that have experienced an increase in mean precipitation greater than $10 \%$ from the pre-urban period to the post-urban period are the Lower Verde Basin stations. The station at Carefree is slightly west of Lower Verde but also exhibits a relatively significant increase $(9 \%)$ over the same period. One sample t-tests were conducted for each mean value in the Lower Verde region to see if the differences relative to the other stations are statistically significant or occurred by chance. In all tests, the two-tailed $\mathrm{P}$ value was less than 0.0001 so by conventional hypothesis testing criteria, the difference is considered extremely statistically significant. Though DB03 did not investigate the pre-urban period, their results also identified the Lower Verde region as the region of elevated median precipitation totals over the period of 1950 to 2000. Stations in other regions have experienced essentially no change or slight decreases in mean precipitation totals. Figure 5 is a time series of monsoon period (July-September) mean precipitation totals for Sunflower (Lower Verde), Phoenix (Urban), and Clifton (Monsoon). The figure suggests that precipitation totals in the Lower Verde station (Sunflower) have trended upward over the 108-year period as compared to Phoenix and Clifton.

\section{ii. Analysis of the Relative Magnitude of Precipitation at the Lower Verde Stations}

Another finding of this study is that other stations in the region with comparable topographic relief and similar (and in some cases more severe) monsoonal conditions have not experienced significant increases in the post-urban period. An analysis similar to DB03 was conducted in which all sites from Table 1 that exhibited a percentage increase greater than ten in mean total precipitation were compared with stations in nearby basins and the monsoon zone. For consistency with DB03, we analyze the relative differences of the median precipitation totals (Table 2) for years 1950-2003 (post urban).

Results in table 2 are consistent with DB03. It is clear that Sunflower in the Lower Verde is the region's wettest station. In part, this is likely due to Sunflower's higher elevation although the two monsoon zone stations have comparable elevations. Sunflower may also be experiencing a combined urban and topographical effect in the posturban period. Lower Verde's Horseshoe Dam and Bartlett Dam sites have median precipitation totals greater than 
sites like Cave Creek and Carefree in the northwest Lower Salt basin even though the elevations are similar (and even smaller in the case of the Carefree station). Not surprisingly, the stations in the Monsoon Zone are generally wetter than the other sites, except Sunflower, which indicates the influence of synoptic scale monsoon forcing, but it is useful to recall from the Table 1 discussion that the Monsoon Zone precipitation totals have remained fairly consistent from the pre-urban to post-urban period.

\section{iii. Hypothesis for the Lower Verde Precipitation Anomaly}

The results of this study were so compelling that we posed the question, "Does the Lower Verde Precipitation Anomaly reveal itself under drought conditions? To answer the question, we used the TRMM rainfall product (TRP) to construct a mean rainfall rate map for the monsoon period of July-September 2003 for the central Arizona region. In figure 6, the TRP estimate of mean rainfall rate reveals an elevated region of rates $30-50 \mathrm{~km}$ northeast of the Phoenix metropolitan area (approximated by the black rectangle) and the influence of mountainous terrain on precipitation as the bluish colors (indicating precipitation) essentially corrolate to the mountains (see figure 4). Heavier rainfall rates on the Mexican border likely reflect both topography and stronger monsoonal precipitation. These results seem to suggest that the processes leading to the anomaly can exist under the most extreme drought conditions.

Shepherd and Burian (2003) presented evidence that convective anomalies over and downwind of Houston, Texas were related to the complex interactions between urban-induced and sea-breeze related dynamics while the role of aerosols remain uncertain. Watson et al. (1994) and DB03 have suggested that convective activity in Phoenix is enhanced by urban-related processes and the topographic relief. During the late morning to early afternoon, thunderstorms are typically confined to the highest terrain (Wallace et al. 1999). Over the central and eastern mountains there is a pronounced mid-afternoon maximum of thunderstorm activity directly attributable to diurnal heating and mountain-valley circulations. Watson et al. (1994b) have identified an early-evening (i.e. 5 to 7 pm LST) maximum in deep monsoonal convection in the Phoenix region.

Phoenix typically exhibits a relatively weak urban heat island (UHI) and sometimes an urban heat sink because large amounts of energy are converted into latent heat rather than sensible heat because of the prevalence of irrigated lands (DB03). Thielen et al. (2000) showed in numerical simulations that when UHIs are weak, surface sensible heat fluxes, convergence, and buoyancy variations that influence rainfall development are most effective at a distance from the central heat source. Baik et al. (2001) also showed that when a heat island is present, two regime 
flows are established. One exhibits a stationary gravity wave near the heating region and the other is characterized by stationary gravity waves near the heating source and an updraft cell downstream from the heating source. In the case of Phoenix, these results suggest that urban-induced convective forcing can be established on the edge of the metropolitan area. Figure 7 is a schematic presenting our hypothesized reasons why the Lower Verde anomaly exists. First, convection from the mountains is established during the daytime through direct heating and mountainvalley thermal circulations. By afternoon, the storms propagate downward and to the west and south releasing evaporation-generated density currents or outflow boundaries as hypothesized by Watson et al. (1994b). Figure 8 uses the TRMM product in a Hovmoller diagram to illustrate the tendency for westward propagation of storms. The diagram plots the longitude-time variation of the mean rainfall rate averaged over the $33^{\circ}-34^{\circ}$ latitude box, including Phoenix and immediate basin sites. The figure illustrates the tendency for convection to form in the mountains and then propagate westward as indicated in this case from August 10-11 2003. Because of the location of the Lower Verde region, the outflow boundaries from storms in this region can most effectively interact with the convergence and flux forcing on the edge of the city.

Additionally, figure 3 pointed out that the lower-middle tropospheric flow on active monsoon days is southeasterly. The resulting urban-mountain convergent region is continually pumped with monsoon moisture from the southeasterly flow. Though speculative, it should be noted that the Phoenix region is likely more moist due to the presence of significant and increasing irrigation and agricultural practices. Moisture advection into the preferred convergence region by southerly flow regimes could enhance convection. Figure 9 is taken from Gaffen and Ross (1999) and illustrates the sign and statistical significance level of station trends in dewpoint temperatures $T d$ for each season based on full-day data. The trends are generally positive and statistically significant, particularly at Phoenix station. Gaffen and Ross (1999) note that locally, anthropogenic modification of the hydrological cycle is important to consider. Within the conterminous United States, the U.S. Geological Survey has estimated that consumptive use of water in agricultural irrigation contributes 100 billion gallons of water per day to the atmosphere, compared with 2800 billion gallons per day from evaporation and transpiration from surface water bodies, land surface, and vegetation. In dry regions during the growing season, the ratio of consumptive use to natural evaporative sources may be greater, and it is possible that long-term increases in evaporation from irrigated fields may be large enough to influence the surface trends at some stations. Numerical simulations using a coupled atmosphere-land surface model will be conducted in future studies to test these hypotheses. 


\section{b. Riyadh}

\section{i. Historical data analysis}

An analysis of GSN mean temperature measurements from 1978 to 1998 for stations at Riyadh (24.4N, 46.4E), Madinah $(24.3 \mathrm{~N}, 35.35 \mathrm{E})$, and Al-Jouf $(29.79 \mathrm{~N}, 40.1 \mathrm{E})$ indicates that urbanized Riyadh may be experiencing a climatological shift towards temperature profile influenced by the well-studied urban heat island. Figure 10 suggests that Riyadh's mean annual temperature has trended upward from 1990-1998. It can be argued that the temperature at the other two stations have also trended upward over this period but the trend is less clear. These results are consistent with Alkolib (2002, hereafter A02) who investigated historical temperature and precipitation for the four Saudi weather stations during the period 1961-1997. These four stations were located at Riyadh in the central part of the country, Dhahran in the east, Jeddah in the west, and Almadinah in the northwest. A02 employed both time series and regression analyses. Five-year centered moving average and regression analyses covering the thirty seven-year period 1961-1997 for each of the four stations was applied to the following data:

$\mathrm{AO} 2$ found that the Riyadh station does exhibit a noticeable increase in temperature with $\mathrm{R} 2=0.39$ and $\mathrm{F}=$ 0.001 - a significant value. A20 attributes this increase to the urban heat island associated with rapid growth at Riyadh over the 36 year period. To determine whether the noticeable increase in Riyadh's temperature trend could be attributed to a heat island effect, A20 compared temperature records from the old airport to the temperature records of the new station at King Khalid International Airport, situated about $20 \mathrm{~km}$ northeast of the old airport. The stations have similar topographical features. In the analysis, it was shown that while both Almadinah and Riyadh show increasing trends, only Riyadh shows a noticeable rise with $\mathrm{R} 2=0.35$ and $\mathrm{F}=0.002-\mathrm{a}$ significant value. This increase is most likely due to a heat island effect.

Of interest for this study, figure 11 a illustrates the trend in total annual precipitation at Riyadh from the GSN data. This result suggests that over the 20-year period, there has been sharp upward trend in rainfall after 1992. Total rainfall at Riyadh exhibits an increase from $\sim 100 \mathrm{~mm}$ in the $1978-1992$ period to $\sim 300$ mm or more after 1992 . Again, these results are consistent with A20 who found a sharp trend upward in mean annual rainfall at Riyadh after 1992 (figure 11b). In the $1996-1997$ period of A20, mean annual precipitation had risen to $\sim 180 \mathrm{~mm}$. While other stations in the study exhibited slight increases over the same period, there maximum values in the 1996-1997 time period are $\sim 100 \mathrm{~mm}$ (Jeddah), $125 \mathrm{~mm}$, (Dharan), and $95 \mathrm{~mm}$ (Almadinah), respectively. This result, though inconclusive, suggests that Riyadh has experienced a significant upward trend in precipitation during the same 
period of time as explosive urban growth such that mean annual (total) rainfall is on the order of $200 \mathrm{~mm}(450 \mathrm{~mm})$. The results are not strongly conclusive in terms of linkages to urbanization, but more research is required to understand why there has been a systematic trending upward in precipitation on the Arabian Peninsula.

\section{ii. Satellite-based analysis}

The dominant precipitation season for Saudi Arabia, relatively speaking, is the period from roughly October to April and is primarily convective. During this period, the descending branch of the Hadley cell is not as much of a convective suppression mechanism as it is during the summer months. The observational network for precipitation is particularly sparse thereby increasing the likelihood that the sparse network will significantly underestimate precipitation (Evans et al. 2004). Additionally, Saudi Arabian convective storms appear in a region where relative humidity is usually less than $40 \%$ and hence a significant proportion of the falling rain evaporates. These factors are driving motivations behind the application of satellite-based rainfall estimates in this study. Unfortunately, reliable, microwave-based (as opposed to infrared-cloud top techniques) high-spatial resolution (e.g. $<25 \mathrm{~km}$ ) estimates of precipitation from satellites have only become available in the last few years. Therefore, we cannot use such data to investigate long-term time series of precipitation. However, we can apply the 3B43 NASA satellite product to investigate whether there are any preferred regions for precipitation in and around the central portion of Saudi Arabia.

Figure 12 is the time series of mean accumulated precipitation from the satellite-based product from January 1998 to May 2003. The mean value is plotted for a 25-km square gridpoint center on Riyadh, Saudi Arabia. The figure indicates that the rainy season is during the Northern hemisphere winter. The results also indicate a bimodal tendency during this period with corresponding peaks in early and late winter, respectively. It should be emphasized that values of rainfall are likely under-estimated because of a "smearing" effect of representing fine convective precipitation events on a fairly coarse gridpoint. At a given ground-based rain gauge, values would likely be much higher. However, if one can accept the inherent resolution and algorithm flaws with the satellite-based approaches, figure 13 indicates the true value of the data. Figure 13a illustrates the ability to resolve a spatial depiction of rainfall over a region that is known to be deficient in ground-based rainfall measurements.

In the figure, it is evident that mountainous terrain west of Riyadh is a primary forcing mechanism for rainfall in the region over this period of time. That region has received over $600 \mathrm{~mm}$ of rainfall over a roughly 5 -year period. Of interest for this study, is the relative maximum near $27.75 \mathrm{~N}$ latitude and $46.75 \mathrm{E}$ longitude. This relative 
maximum is located roughly $50-75 \mathrm{~km}$ north of the urban Riyadh area. Under any type of flow with a southerly component, this region would be considered the downwind region of Riyadh. This distance displacement for urbaninduced rainfall anomalies is very consistent with results from the famous METROMEX study (Changnon et al. 1981) and more recent studies by Shepherd et al. (2002). It is tempting to attribute the anomaly to topography but figure 13b suggests that this particular regions is does not have significant relief. Recalling a previous discussion, Thielen et al. (2000) and Baik et al. (2001) have shown that weak or small heat islands result in surface sensible heat fluxes, convergence, and buoyancy variations that influence rainfall development being most effective at a distance from the central heat source. According to Sahin and Aksakal (1999) prevailing low-level wind flow during the rainy season is North-Northwesterly. Under this scenario, it is possible that the low-level prevailing flow interacts with the weak urban-induced circulations on the northern fringe of Riyadh to establish a preferred convergence or rising branch region. Additionally, irrigation has likely altered the moisture availability in ways similar Phoenix (e.g., figure 9). However, at this point, this hypothesis has not been confirmed with numerical simulations.

\section{Discussion and Conclusions}

This study has employed a unique 108-year precipitation data record, global observing network and satellitebased to identify statistically significant anomalies in rainfall downwind of the Phoenix, Arizona urban region and a possible urban-induced anomaly just north of Riyadh, Saudi Arabia.. Our analysis showed that during the monsoon rainfall season (July, August, September) locations in the northeastern suburbs and exurbs of the Phoenix metropolitan urban area (the so-called "anomaly region"), primarily the Lower Verde Basin, have experienced statistically significant increases in mean precipitation of 12 to 14 percent from a pre-urban (1895-1949) to posturban (1950-2003) period. Additionally, mean and median post-urban precipitation totals in the anomaly region were significantly greater, in the statistical sense, than regions west of the city and in nearby mountainous regions of similar or greater topography. Further analysis of satellite-based rainfall totals for the summer of 2003 also revealed the existence of the anomaly region even though the arid southwest experienced severe drought during the period. More significant orographic features do not correspond to the location of the anomaly region, and statistically significant precipitation changes are found in the anomaly region when pre- and post- urban data are analyzed. For the Saudi Arabian case, results from our analysis of gauge data did not inclusive link any precipitation trends with urbanization. However, satellite-based analyses revealed a relative maxima in accumulated rainfall $50-100 \mathrm{~km}$ north of Riyadh. 
Future work will utilize coupled atmosphere and land surface models to test the hypothesis that urbantopographic dynamics and increased moisture from irrigation practices alter precipitation in arid regimes. The role of aerosols must also be investigated. The implications of this research are wide. The results continue to suggest that weather and climate models must adequately resolve the urban environment (e.g. land use, aerosols). The results also indicate that even a fairly significant large synoptic-scale process (e.g. monsoon) might possibly interact with local and regional mesoscale circulations. Finally, our results highlight how sensitive the water cycle can be to anthropogenic forcings, even under extreme drought or arid conditions.

Acknowledgements: The author thanks Ramesh Kakar (NASA HQ) for support of this work under the NASA Precipitation Measurement Missions program and the 3B42/3B43 team of Bob Adler, George Huffman, and colleauges. 


\section{References}

Akber, A., E. Al-Awadi, and H. Ghoneim, 2001: Water resources management in developing countries: A case study from Kuwait. In Integrated water resource management, ed. M. A. Marin and S. P. Simonovic, 213-20. Integrational Association of Hydrological Sciences (IAHS) Publication no. 272. Wallingford, Oxfordshire, U.K.: IAHS Press.

Alkolibi, F., 2002: Possible effects of global warming on agriculture and water resources in Saudi Arabia: Impacts and responses. Climatic Change, 54, 225-245

Baik, J.-J., Y.H. Kim, and H.Y. Chun, 2001: Dry and moist convection forced by an urban heat island. J. Appl. Meteor., 40, 1462-1475.

Balling, R. C., Jr., and S. W. Brazel, 1987: Diurnal variations in Arizona monsoon precipitation frequencies. Mon. Wea. Rev., 115, 342-346

Bornstein, R., and Q. Lin, 2000: Urban heat islands and summertime convective thunderstorms in Atlanta: three cases studies. Atm. Env., 34, 507-516.

Burian, S.J. and J. M. Shepherd, 2005: Effects of Urbanization on the Diurnal Rainfall Pattern in Houston: Hydrological Processes: Special Issue on Rainfall and Hydrological Processes, 19, 1089-1103.

Changnon, S.A., R.G. Semonin, A. H. Auer, R.R. Braham, and J. Hales, 1981: METROMEX: $A$ Review and Summary. Amer. Meteor. Soc. Monogr., 18, 81 pp.

Daly, C., W. P. Gibson, G.H. Taylor, G. L. Johnson, P. Pasteris, 2002: A knowledge-based approach to the statistical mapping of climate. Climate Research, 22: 99-113.

Diem, J.E., and D.P. Brown, 2003: Anthropogenic impacts on summer precipitation in central Arizona, U.S.A. The Professional Geographer, 55(3), 343-355.

Dixon, P.G., and T.L. Mote, 2003: Patterns and causes of Atlanta's urban heat island-initiated precipitation. J. Appl. Meteor., 42, 1273-1284

El-Sharif, A. R., 1985: Water supply problems of Riyadh, Saudi Arabia. GeoJournal 11:239-43. Progress in Physical Geography 22:477-520.

Gaffen, Dian J., and Ross, Rebecca J., 1999: Climatology and Trends of U.S. Surface Humidity and Temperature Journal of Climate, 1999 12: 811-828 
Hidalgo, H.G., 2004: Climate precursors of multidecadal drought variability in the western

United States, Water Resources Res., (in press).

Huff, F. A., 1986: Urban hydrological review. Bull. Amer. Meteor. Soc., 67, 703-712.

Huffman, G.J., R.F. Adler, E.F. Stocker, D.T. Bolvin, E.J. Nelkin, 2003: Analysis of TRMM 3-

Hourly Multi-Satellite Precipitation Estimates Computed in Both Real and Post-Real Time. Combined Preprints CD-ROM, 83rd AMS Annual Meeting, Poster P4.11 in: 12th Conf. on Sat. Meteor. and Oceanog., 9-13 Feb. 2003, Long Beach, CA, 6 pp. (Available as $\mathrm{ftp} / / /$ agnes.gsfc.nasa.gov/pub/huffman/papers/12th_sat.proc.pdf)

Inoue, T., and F. Kimura, 2004: Urban effects on low-level clouds around the Tokyo metropolitan area on clear summer days, Geophys. Res. Lett., 31, L05103, doi: 10.1029/2003GL018908.

Karamouz, M., S. Torabi, B. Zahraie, S. Araghi-Nejhad, and M. Shahsavari, 2001: An integrated approach to water resources development of the Tehran region in Iran. Journal of the American Water Resources Association, 37, 1301-11.

López, R. E., R. L. Holle, A. I. Watson, and J. Skindlov, 1997: Spatial and temporal distributions of lightning over Arizona from a power utility perspective. J. Appl. Meteor., 36, 825-831.

Metz. Helen, 1993: Saudi Arabia: a country study: Federal Research Division, Library of Congress, Washington, D. C., p. 107.

Modaihsh, A. S., 1997: Characteristics and composition of the falling dust sediments on Riyadh City, Saudi Arabia. Journal of Arid Environments, 36, 211-23.

Molders, N., and M.A. Olson, 2004: Impact of urban effects on precipitation in high latitudes. J. of Hydromet., 5, 409-429.

Orville, R., G. Huffines, J.N. Gammon, R. Zhang, B. Ely, S. Steiger, S. Phillips, S. Allen, and W. Read, 2001: Enhancement of cloud-to-ground lightning over Houston Texas. Geophys. Res. Ltr., 28, 2597-2600.

Piechota, T., J. Timilsena, G. Tootle, and H. Hidalgo, 2004: The western U.S. drought: How bad is it? Eos, Vol. 85 (32), pp. 301, 304.

Qureshi, S., and N. Khan, 1994: Estimation of climatic transition in Riyadh (Saudi Arabia) in global warming perspective. GeoJournal, 33, 423-32. 
Rex, T.R., 2000: Development of metropolitan Phoenix: Historical, current, and future trends.

Phoenix: Morrison Institute for Public Policy, Arizona State University.

Sahin, A.Z., and A. Aksakal, 1999: A statistical analysis of wind energy potential at the eastern region of

Saudi Arabia. International Journal of Energy Research, 23, 909-917.

Shepherd, J.M., 2005: A Review of Current Investigations of Urban-Induced Rainfall and

Recommendations for the Future, Earth Interactions, (in press).

Shepherd, J.M., and S.J. Burian, 2003: Detection of urban-induced rainfall anomalies in a major coastal city. Earth Interactions, 7, 1-17.

Shepherd, J. M., H. Pierce, and A. J. Negri, 2002: Rainfall modification by major urban areas:

Observations from spaceborne rain radar on the TRMM satellite. J. of Appl. Meteor., 41, 689701.

Thielen, J., W. Wobrock, A. Gadian, P.G. Mestayer, and J.-D. Creutin, 2000: The possible influence of urban surfaces on rainfall development: a sensitivity study in 2D in the meso-gamma scale. Atm. Res., 54, 15-39

Wallace, C.E., R.A., Maddox, and K.W., Howard, 1999: Summertime Convective Storm Environments in Central Arizona: Local Observations. Weather and Forecasting:

Vol. 14, No. 6, pp. 994-1006

Watson, A. I., R. E. López, and R. L. Holle, 1994a: Cloud to ground lightning and upper-air patterns during burst and breaks in the southwest monsoon. Mon. Wea. Rev., 122, $1726-1739$.

,-- , and ——, 1994b: Diurnal cloud-to-ground lightning patterns in Arizona during the southwest monsoon. Mon. Wea. Rev., 122, 1716-1725. 
Table 1-Comparison of pre-urban (1895-1949) and post-urban (1950-2003) mean precipitation totals in the Phoenix and surrounding basin areas.

\begin{tabular}{|c|c|c|c|c|c|c|}
\hline Location & Latitude & Longitude & $\begin{array}{l}\text { Region and } \\
\text { Elevation (m) }\end{array}$ & $\begin{array}{l}\text { Pre-Urban (1895- } \\
1949) \quad \text { Mean } \\
\text { Precipitation (mm) }\end{array}$ & $\begin{array}{l}\text { Post-Urban } \\
(1950-2003) \\
\text { Mean } \\
\text { Precipitation } \\
(\mathrm{mm})\end{array}$ & $\begin{array}{l}\text { Percent } \\
\text { Change }\end{array}$ \\
\hline $\begin{array}{l}\text { Phoenix } \\
\text { (downtown) }\end{array}$ & 33.4 & 111.9 & $\begin{array}{l}\text { Urban } \\
(610 \mathrm{~m})\end{array}$ & 23.66 & 23.39 & $-1.1 \%$ \\
\hline $\begin{array}{l}\text { Phoenix } \\
\text { (SW) }\end{array}$ & 33.0 & 112.5 & $\begin{array}{l}\text { Urban } \\
(304 \mathrm{~m})\end{array}$ & 22.74 & 22.38 & $-1.5 \%$ \\
\hline El Mirage & 33.6 & 112.3 & $\begin{array}{l}\text { Urban } \\
(\sim 610 \mathrm{~m})\end{array}$ & 21.00 & 21.63 & $3.0 \%$ \\
\hline Buckeye & 33.3 & 112.5 & $\begin{array}{l}\text { Urban } \\
(304 \mathrm{~m})\end{array}$ & 23.26 & 22.28 & $-4.2 \%$ \\
\hline Duncan & 32.7 & 109.1 & $\begin{array}{l}\text { Monsoon } \\
(1160 \mathrm{~m})\end{array}$ & 41.41 & 43.04 & $3.9 \%$ \\
\hline Clifton & 33.0 & 109.2 & $\begin{array}{l}\text { Monsoon } \\
(1150 \mathrm{~m})\end{array}$ & 46.04 & 46.20 & $0.3 \%$ \\
\hline Kelvin & 33.1 & 110.9 & $\begin{array}{l}\text { Middle Gila } \\
(550 \mathrm{~m})\end{array}$ & 37.73 & 37.15 & $-1.5 \%$ \\
\hline Florence & 33.0 & 111.3 & $\begin{array}{l}\text { Middle Gila } \\
(460 \mathrm{~m})\end{array}$ & 26.70 & 28.05 & $3.2 \%$ \\
\hline $\begin{array}{l}\text { Stewart } \\
\text { Mtn }\end{array}$ & 33.5 & 111.5 & $\begin{array}{l}\text { East Lower } \\
\text { Salt }(430 \mathrm{~m})\end{array}$ & 33.68 & 34.78 & $3.2 \%$ \\
\hline $\begin{array}{l}\text { Roosevelt } \\
\text { Dam }\end{array}$ & 33.6 & 111.1 & $\begin{array}{l}\text { East Lower } \\
\text { Salt }(650 \mathrm{~m})\end{array}$ & 38.51 & 40.93 & $6.2 \%$ \\
\hline Sunflower & 33.9 & 111.4 & $\begin{array}{l}\text { Lower Verde } \\
(1160 \mathrm{~m})\end{array}$ & 58.95 & 65.91 & $11.8 \%$ \\
\hline $\begin{array}{l}\text { Horseshoe } \\
\text { Dam }\end{array}$ & 33.9 & 111.7 & $\begin{array}{l}\text { Lower Verde } \\
(615 \mathrm{~m})\end{array}$ & 34.21 & 38.19 & $11.6 \%$ \\
\hline $\begin{array}{l}\text { Bartlett } \\
\text { Dam }\end{array}$ & 33.8 & 111.6 & $\begin{array}{l}\text { Lower Verde } \\
(500 \mathrm{~m})\end{array}$ & 29.48 & 33.59 & $13.9 \%$ \\
\hline Cave Creek & 33.7 & 112.0 & $\begin{array}{l}\text { NW Lower } \\
\text { Salt }(490 \mathrm{~m})\end{array}$ & 21.64 & 22.91 & $5.8 \%$ \\
\hline Carefree & 33.8 & 111.9 & $\begin{array}{l}\text { NW Lower } \\
\text { Salt }(760 \mathrm{~m})\end{array}$ & 27.55 & 30.05 & $9.0 \%$ \\
\hline
\end{tabular}


Table 2-Relative Differences (mm) between Median Summer Precipitation Totals at Lower Verde Stations and other study station. and (Years 1950-2003).

\begin{tabular}{|l|l|l|l|l|}
\hline Location & $\begin{array}{l}\text { Bartlett Dam } \\
(500 \mathrm{~m})\end{array}$ & $\begin{array}{l}\text { Horseshoe Dam } \\
(615 \mathrm{~m})\end{array}$ & $\begin{array}{l}\text { Sunflower } \\
(1,160 \mathrm{~m})\end{array}$ & Region \\
\hline $\begin{array}{l}\text { Phoenix (downtown) } \\
(610 \mathrm{~m})\end{array}$ & $\mathbf{+ 7 . 0 5}$ & $\mathbf{+ 1 2 . 9 7}$ & $\mathbf{+ 4 0 . 0 3}$ & urban \\
\hline Phoenix (SW) $(304 \mathrm{~m})$ & $\mathbf{+ 8 . 4 1}$ & $\mathbf{+ 1 4 . 3 3}$ & $\mathbf{+ 4 1 . 3 9}$ & urban \\
\hline El Mirage $(\sim 610 \mathrm{~m})$ & $\mathbf{+ 1 1 . 6 4}$ & $\mathbf{+ 1 7 . 5 6}$ & $\mathbf{+ 4 4 . 6 2}$ & urban \\
\hline Buckeye $(304 \mathrm{~m})$ & $\mathbf{+ 1 0 . 6 8}$ & $\mathbf{+ 1 6 . 6 0}$ & $\mathbf{+ 4 3 . 6 6}$ & urban \\
\hline Duncan $(1,160 \mathrm{~m})$ & -11.43 & -5.51 & $\mathbf{+ 2 1 . 5 5}$ & $\begin{array}{l}\text { monsoon } \\
\text { zone }\end{array}$ \\
\hline Clifton $(1,150 \mathrm{~m})$ & -19.91 & -12.12 & $\mathbf{+ 1 4 . 9 4}$ & $\begin{array}{l}\text { monsoon } \\
\text { zone }\end{array}$ \\
\hline Kelvin $(550 \mathrm{~m})$ & -7.06 & -1.14 & $\mathbf{+ 2 5 . 9 2}$ & middle gila \\
\hline Florence $(460 \mathrm{~m})$ & $\mathbf{+ 3 . 4 5}$ & $\mathbf{+ 9 . 3 7}$ & $\mathbf{+ 3 6 . 4 3}$ & middle gila \\
\hline Stewart Mtn $(430 \mathrm{~m})$ & -2.73 & $\mathbf{+ 3 . 1 9}$ & $\mathbf{+ 3 0 . 2 5}$ & lower salt \\
\hline $\begin{array}{l}\text { Roosevelt Dam }(650 \\
\text { m) }\end{array}$ & $-\mathbf{9 . 9}$ & $-\mathbf{+ 3 . 9 8}$ & $\mathbf{+ 2 3 . 0 8}$ & lower salt \\
\hline Cave Creek $(490 \mathrm{~m})$ & $\mathbf{+ 7 . 8 3}$ & $\mathbf{+ 1 4 . 2 5}$ & $\mathbf{+ 4 1 . 3 1}$ & $\begin{array}{l}\text { nw lower } \\
\text { salt }\end{array}$ \\
\hline Carefree $(760 \mathrm{~m})$ & $\mathbf{+ 1 . 8}$ & $\mathbf{+ 7 . 7 9}$ & $\mathbf{+ 3 4 . 8 5}$ & $\begin{array}{l}\text { nw lower } \\
\text { salt }\end{array}$ \\
\hline
\end{tabular}




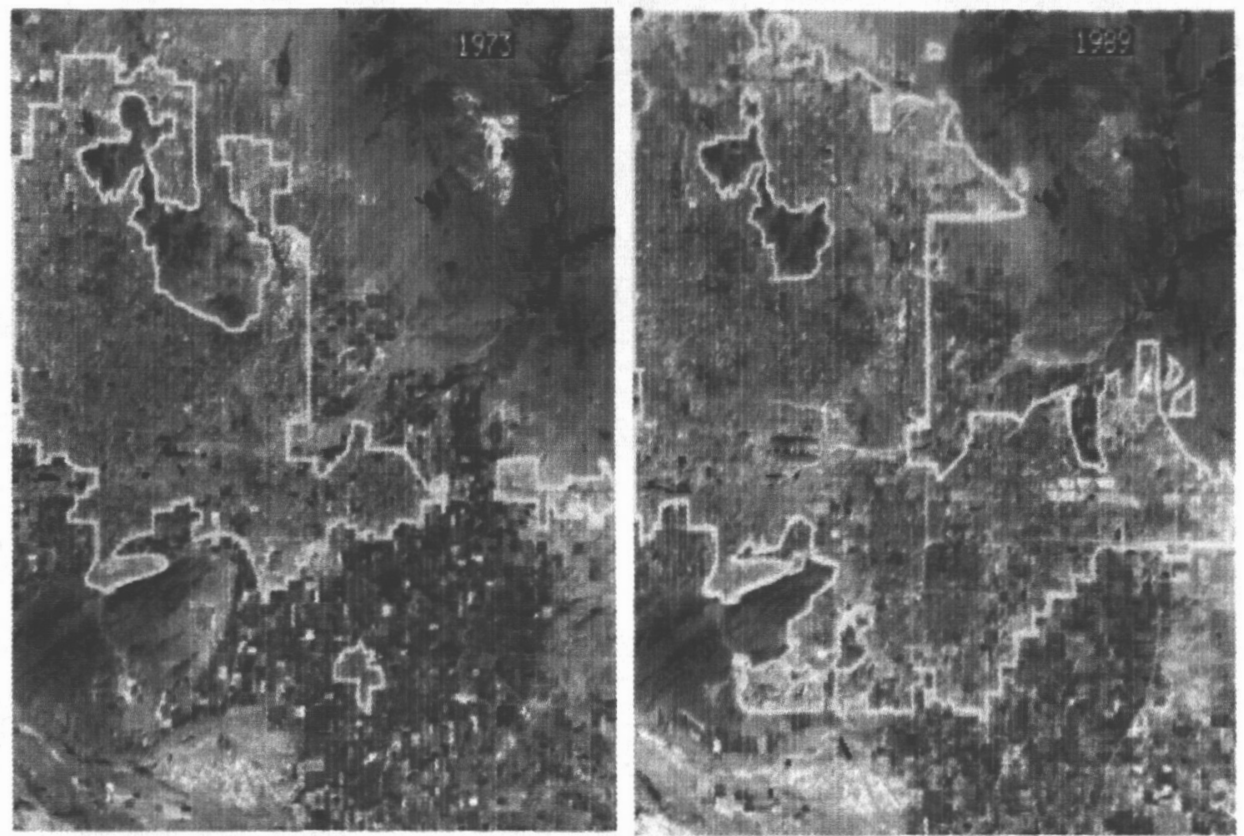

Figure 1-LANDSAT images illustrating the growth of the Phoenix metropolitan area from 1973 to 1989. The yellow outline encompasses the urban region. Red colors are crops or vegetation.

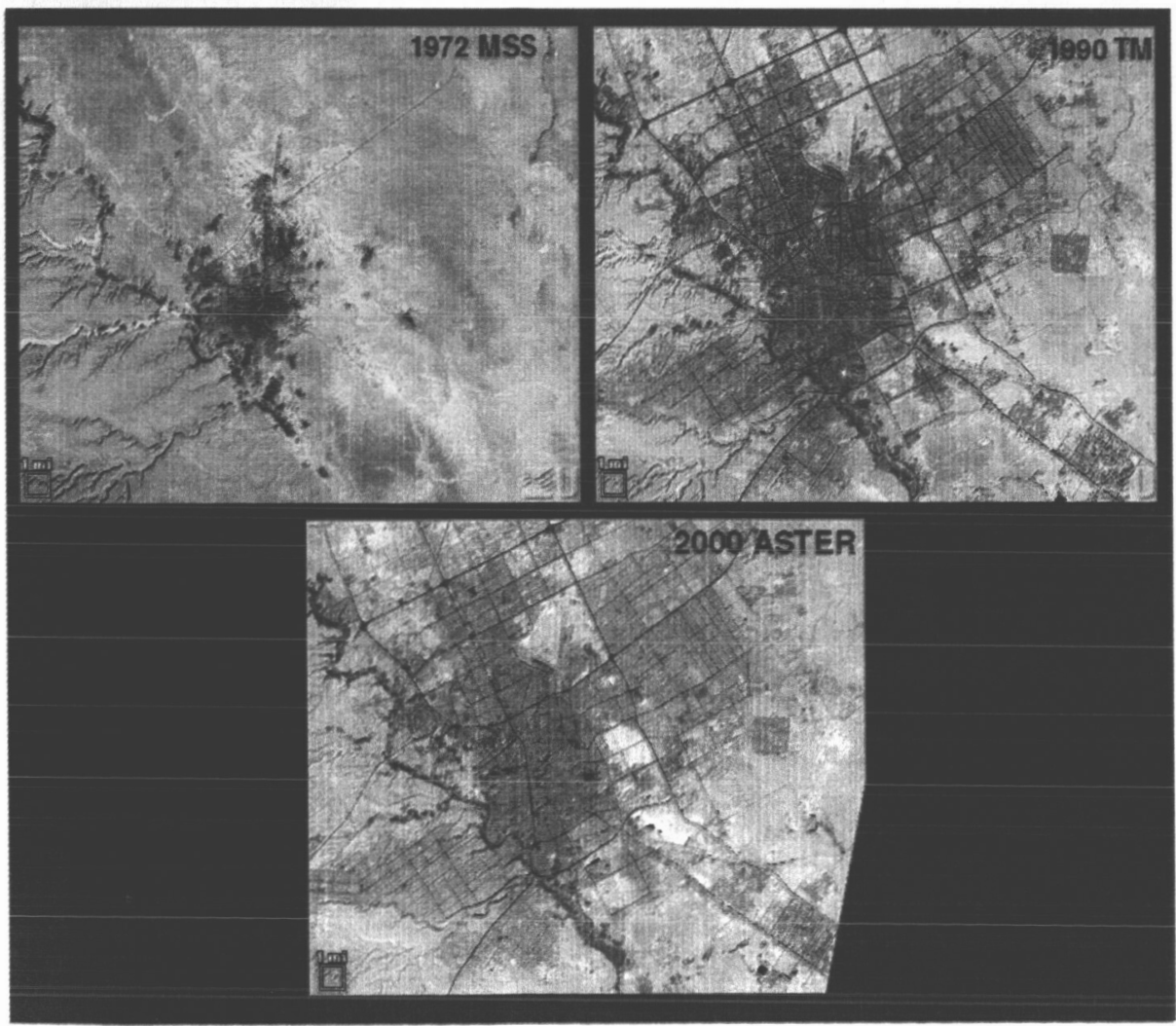

Figure 2-LANDSAT and ASTER satellite images of the growth of Riyadh, Saudi Arabia from 19722000. Grey areas represent urban surfaces, and red areas represent irrigated land. 


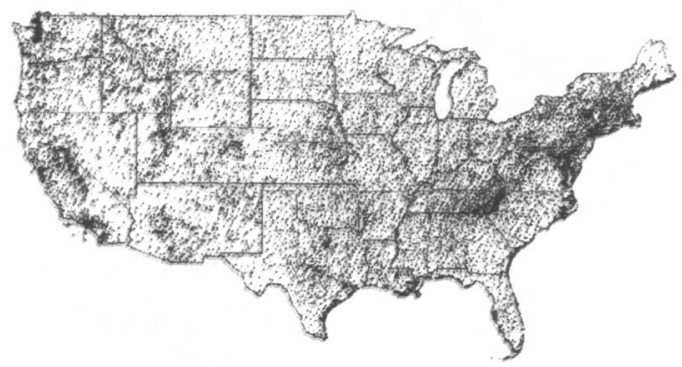

Figure 3- Map of approximately $\sim 12,600$ stations comprising the Spatial Climate Analysis Service 108year precipitation time series. (http://www, ocs, oregonstate,edu/prism/)

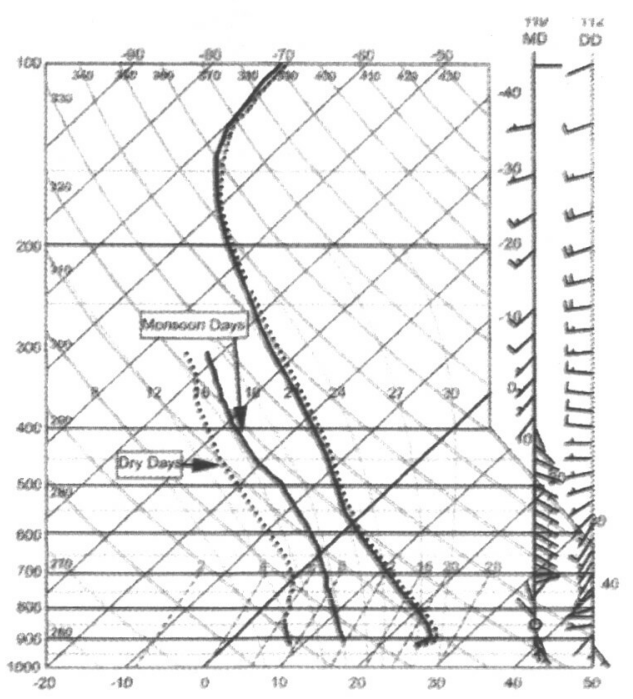

Figure 4-Mean monsoon (MD) and dry (DD) soundings for south-central Arizona (following Wallace et al. 1999) 


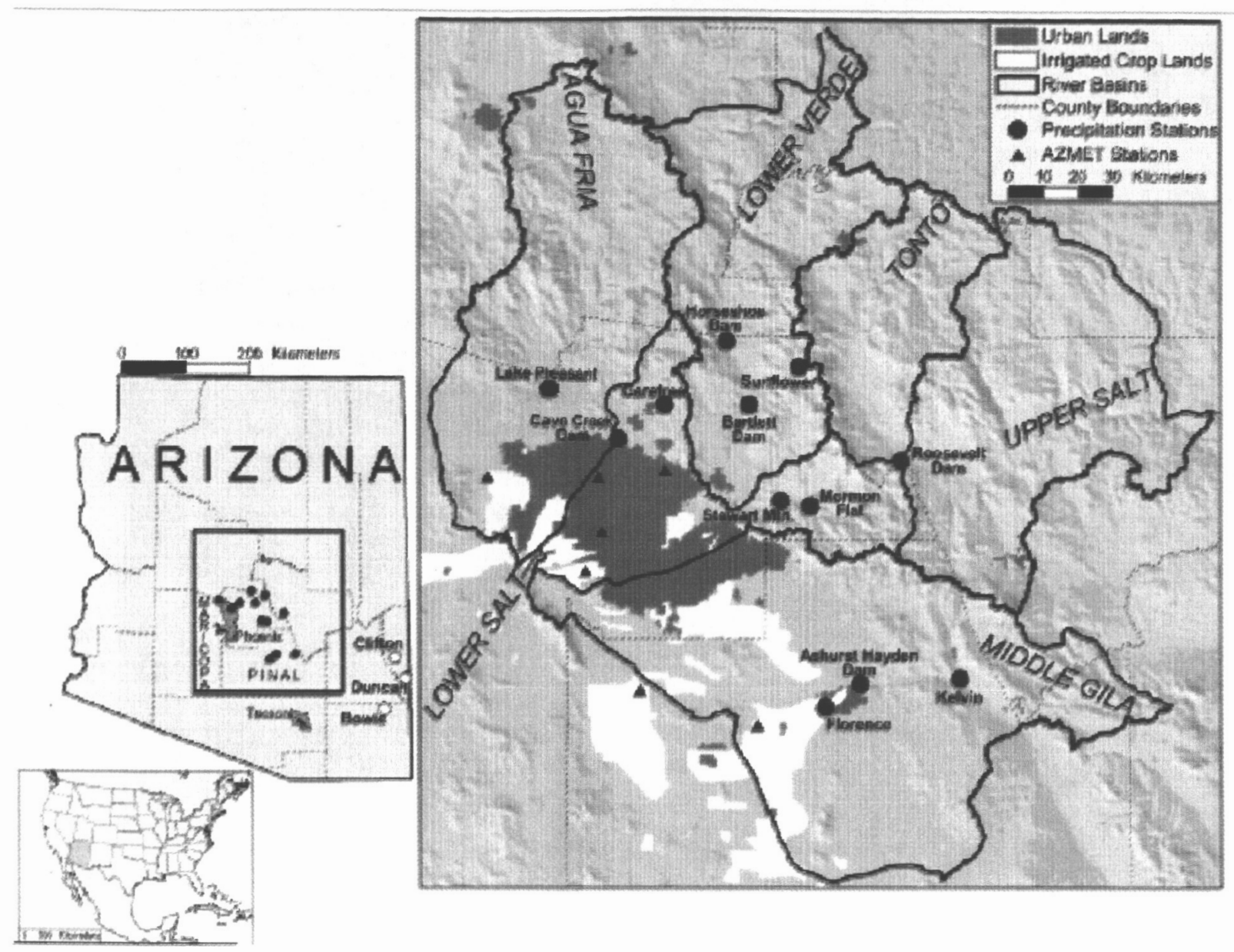

Figure 5-Location of stations examined relative to central Arizona basins. Urban and irrigated cropland were identified using a 1999 Landsat Enhanced Thematic Mapper scene (figure taken from Diem and Brown 2003) 


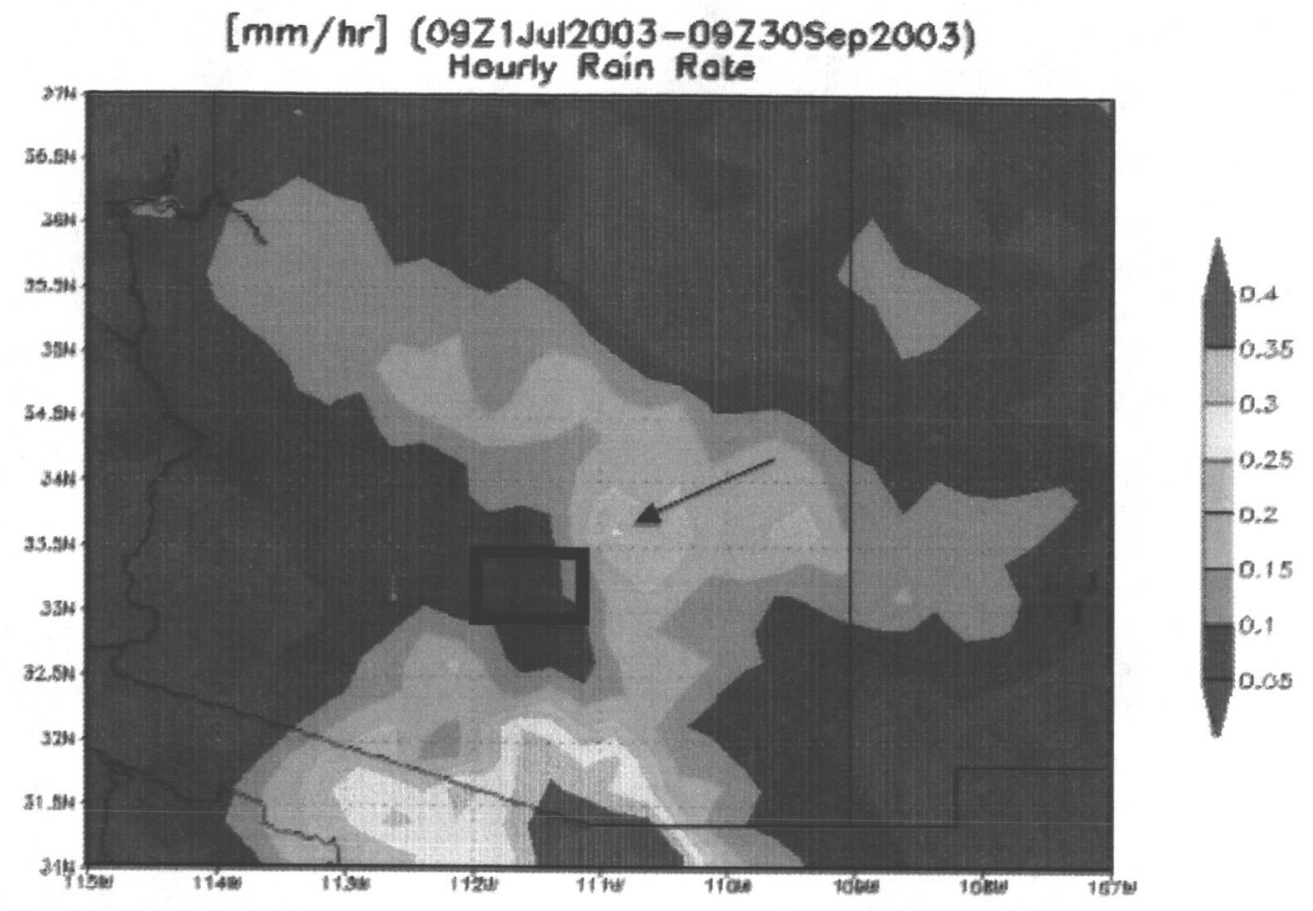

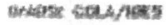

Figure 6-Mean rainfall rates for the 2003 monsoon period (July-September) derived from the real-time TRMM 3B42 rainfall product. Black rectangle is the approximate location of the Phoenix urban area.

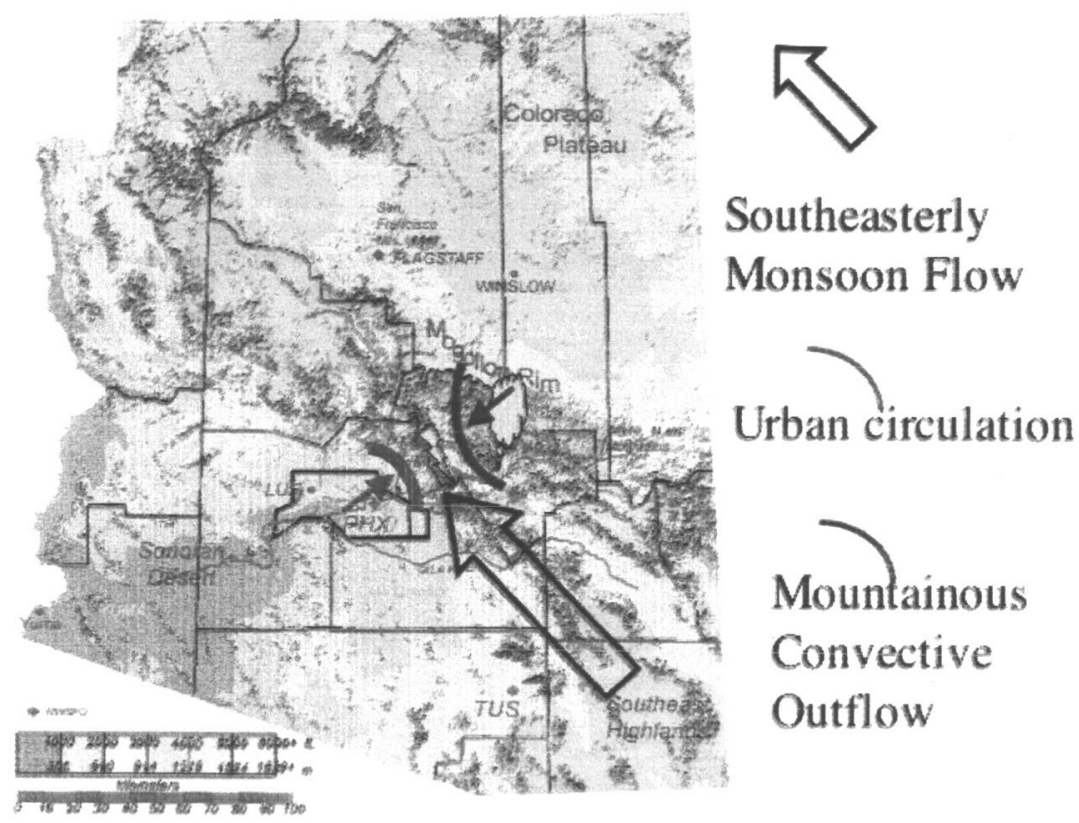

Figure 7-Schematic of the hypothesized urban-topographic interactions in the Phoenix region during a typical monsoon season. 


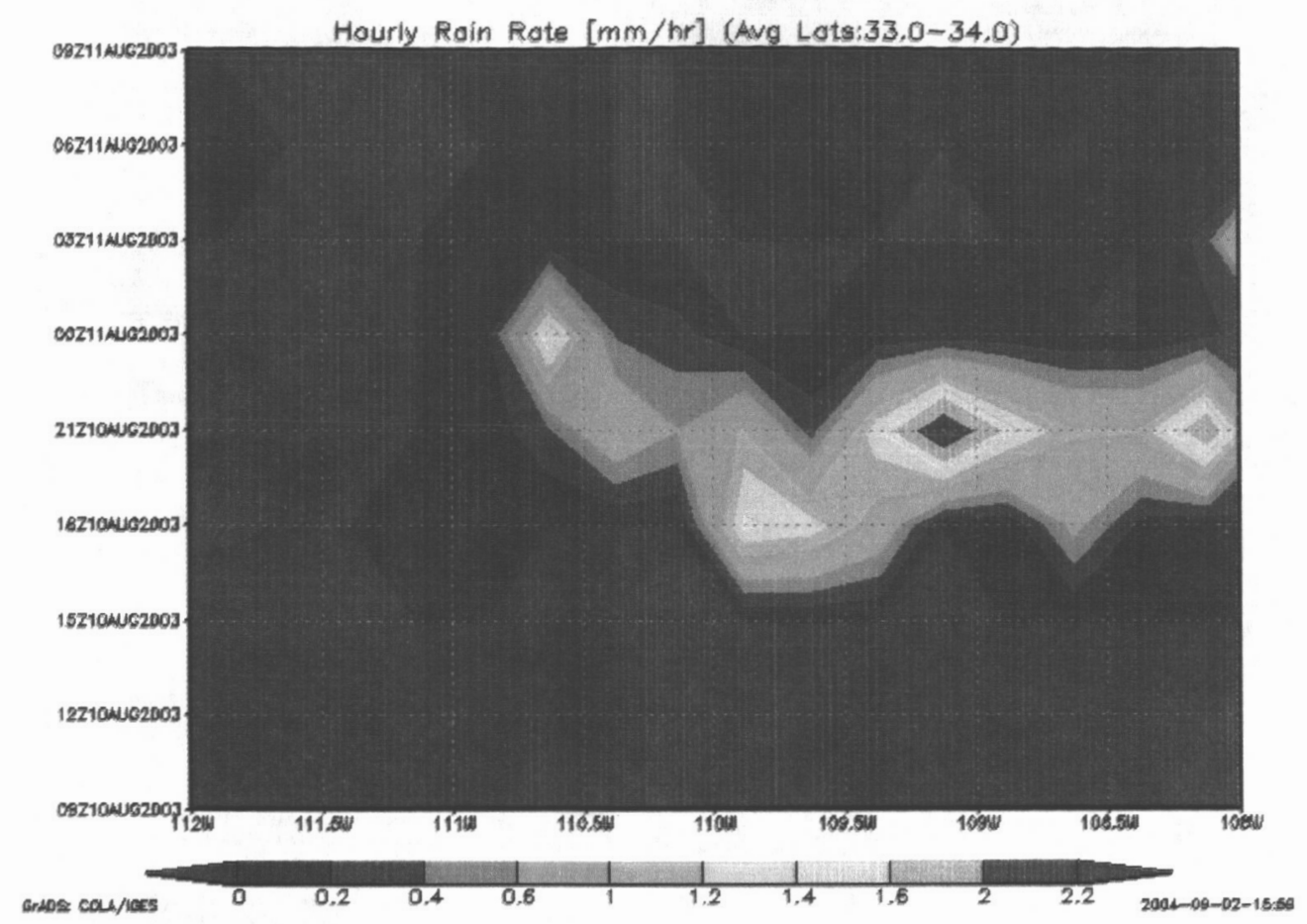

Figure 8-TRMM 3B42RT Hovmoller diagram illustrating the tendency for Phoenix area monsoon convection to develop in the mountains east of Phoenix then propagate down in the Phoenix-urban valley area with a westward component. The plot represents mean rainfall rate for a convective period of 09 UTC 10 August to 09 UTC 11 August. 

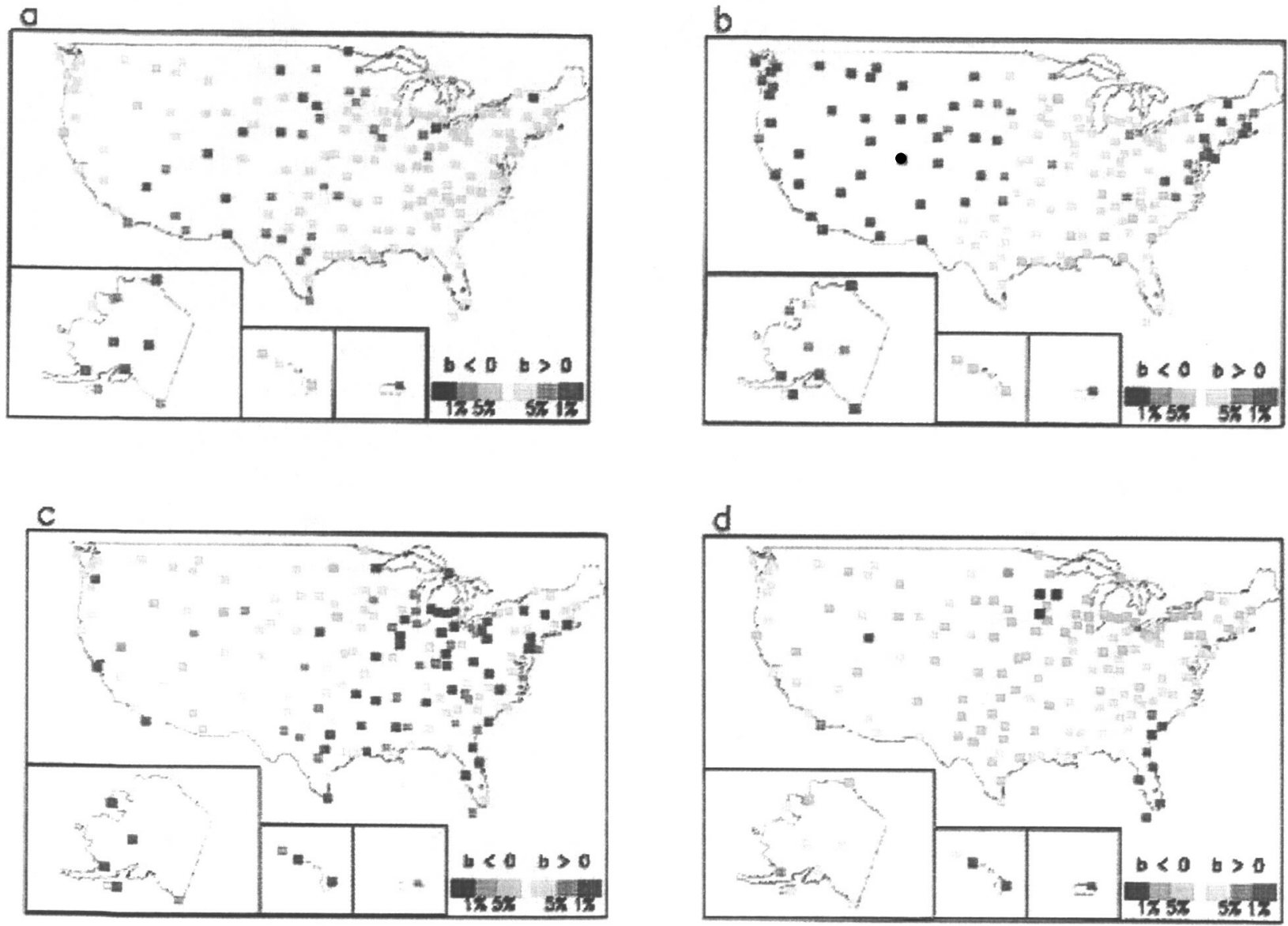

Figure 9- Sign and statistical significance of trends, $b$, in dewpoint (K decade-1) for (a) winter, (b) spring, (c) summer, and (d) fall based on full-day data. Statistical significance, indicated by the two-sided probability that the rank-order correlation between dewpoint and time is not different from zero, is shown for the 0.05 and 0.01 confidence levels (from Gaffen and Ross 1999). 

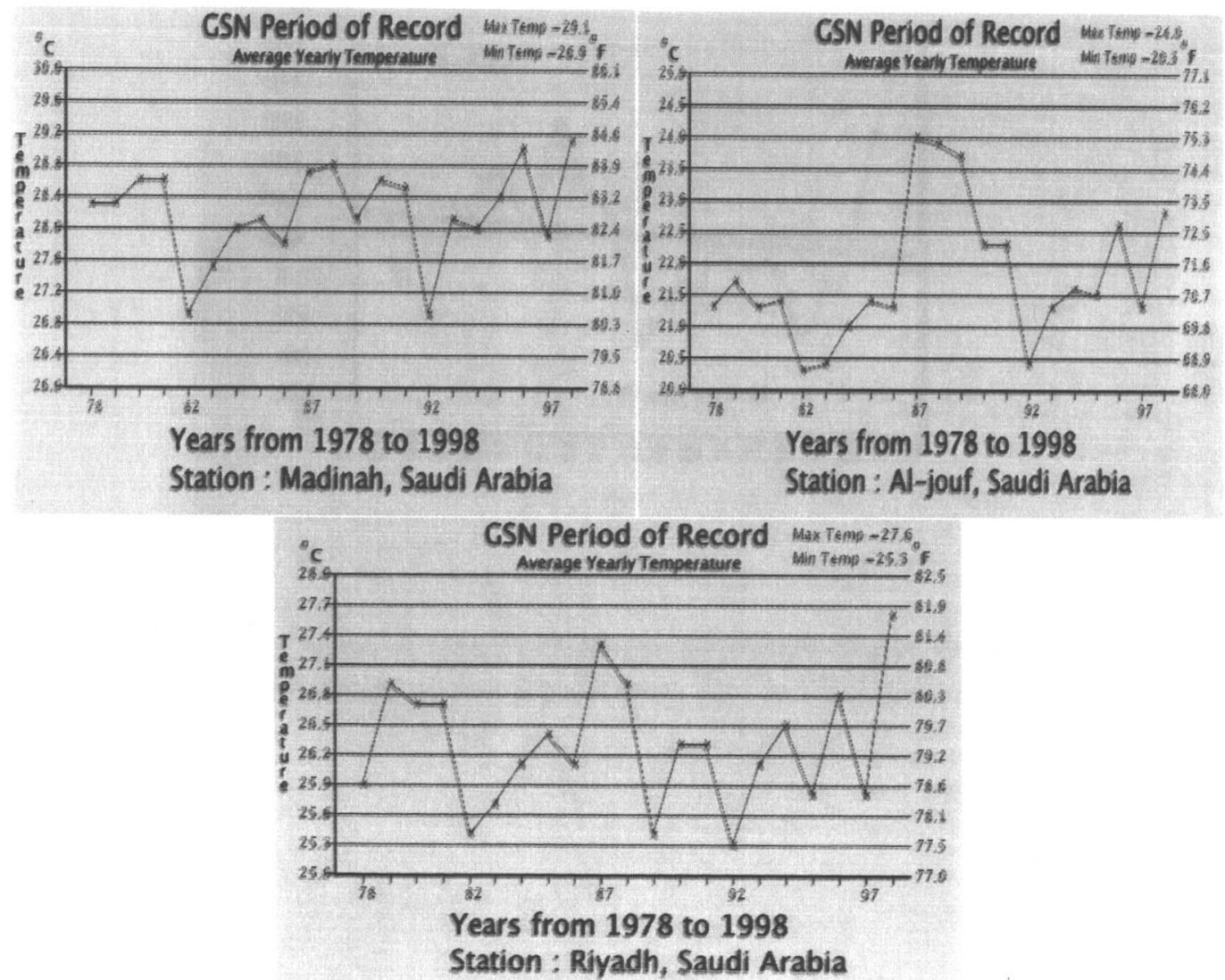

Figure 10-GCOS Surface Network temperature records (1978 to 1998) for Madinah, Al-jouf, and Riyadh. 

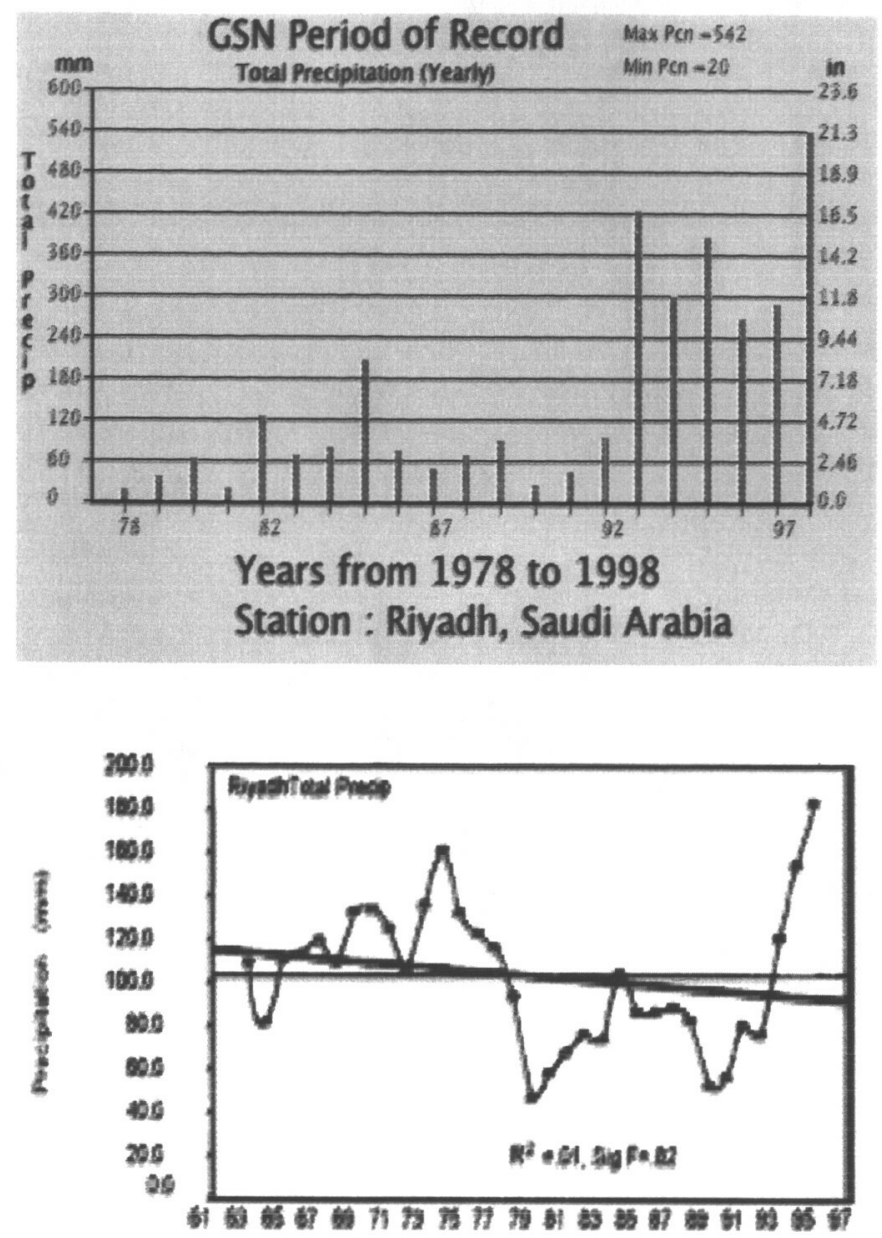

Figure 11 a. (top) GCOS Surface Network record of total annual precipitation at Riyadh (1978 to 1998) b. (bottom) Trend of mean annual precipitation at Riyadh from 1961 to 1997 (following Alkolib (2002)), 


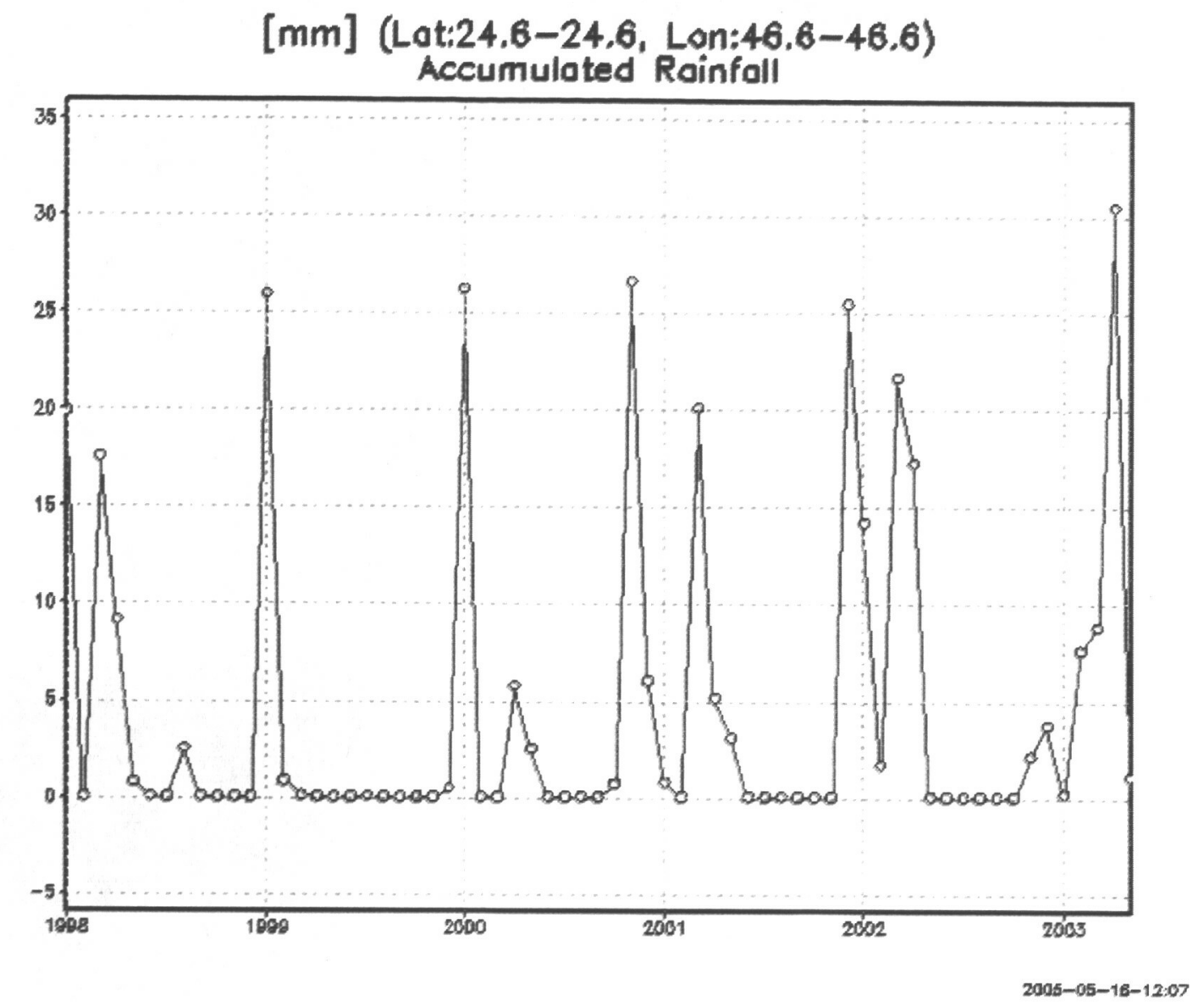

Figure 12-Mean precipitation time series (January 1998 to May 2002) as retrieved by the satellite-based $3 \mathrm{~B} 43$ precipitation product for a $25-\mathrm{km}$ by $25-\mathrm{km}$ pixel centered on Riyadh, Saudi Arabia. 


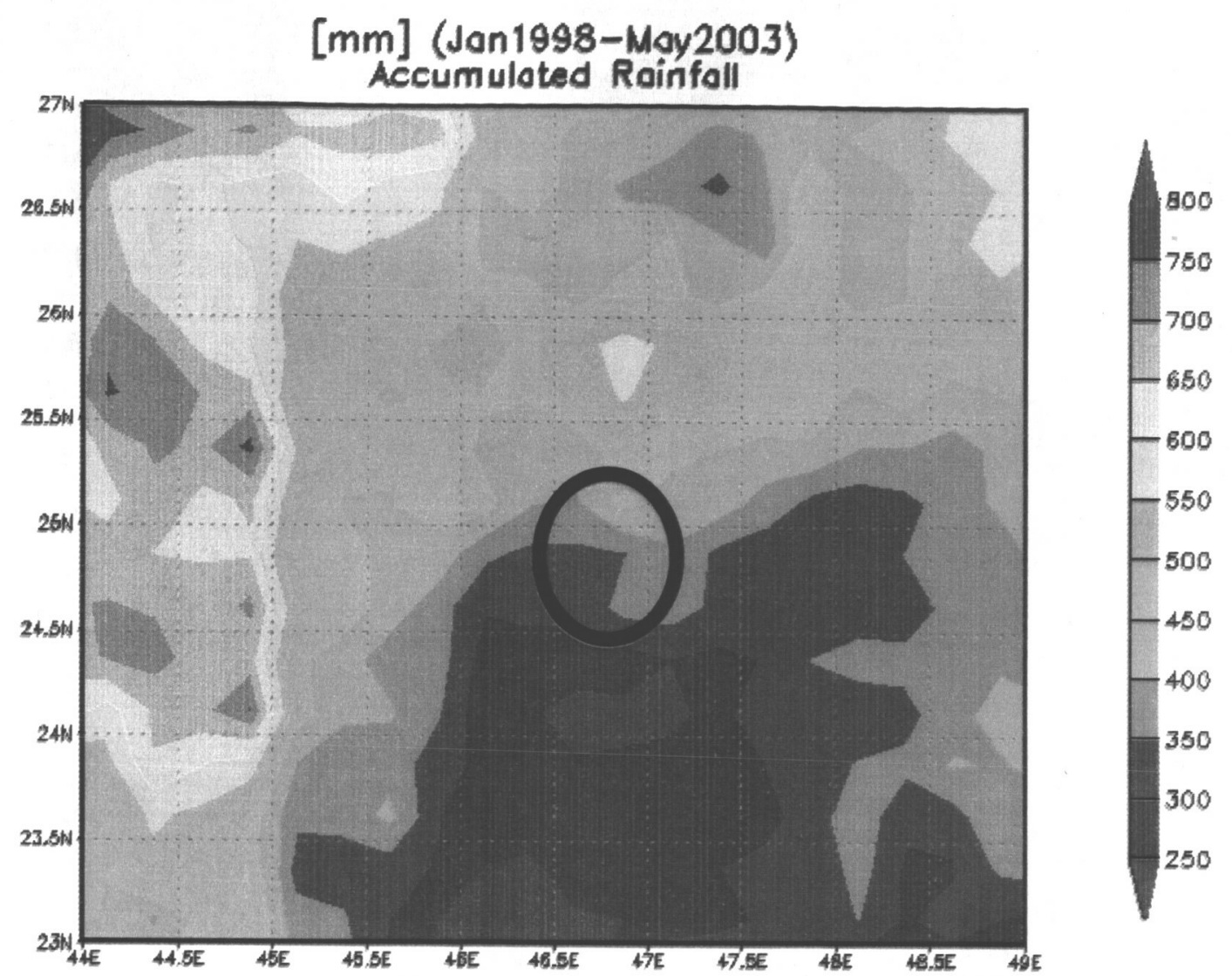

BrMDS COL/IEES

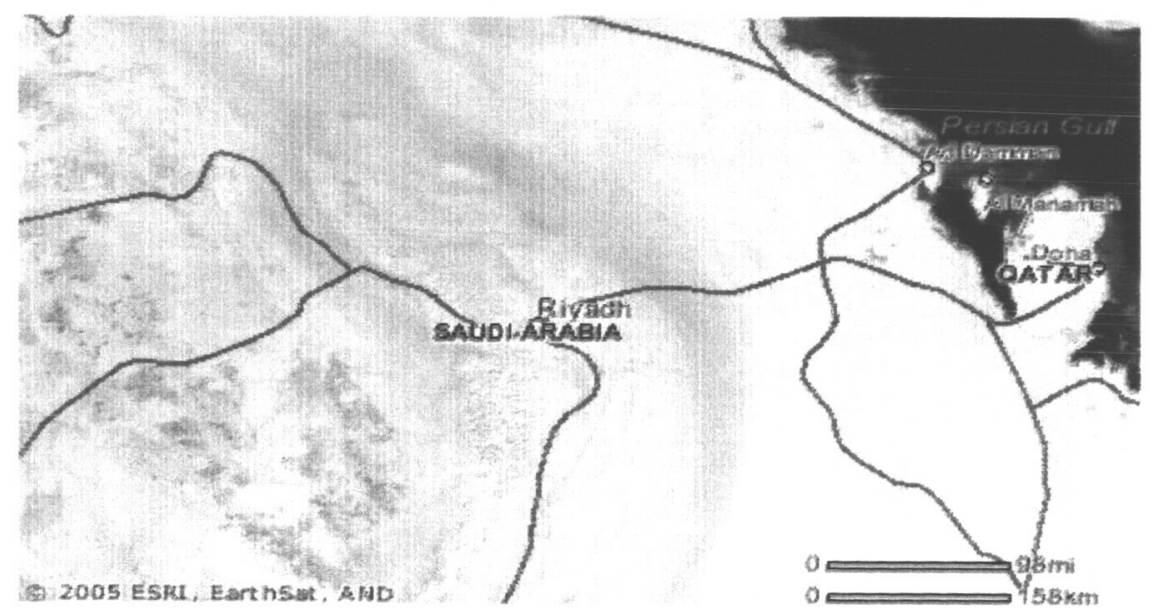

Figure 13 a. (top) 3B43 Satellite-based estimate of mean precipitation ( $\mathrm{mm}$ ) from January 1998 to May 2003. The black circle is the approximate location of the Riyadh urban area. b. (bottom) Relief map centered on Riyadh with significant topographic relief to the west of Riyadh (map courtesy of ESRI, EarthSat, and National Geographic). 


\title{
Popular Summary
}

\section{Evidence of Urban-Induced Precipitation Variability in Arid Climate Regimes}

\section{Submitted to Journal of Arid Environments}

\author{
J. Marshall Shepherd \\ NASA/GSFC
}

\begin{abstract}
Water is essential to life in the Earth system. The water cycle components that sustain life are becoming more scarce and polluted. The most recent (1999-2004) drought experienced in the southwestern United States is the seventh worst in the approximately 500-year proxy tree-ring record. As a result, many regions contemplated "drought emergencies" in which severe water restrictions are implemented. Though larger weather and climate processes likely control drought processes, there is increasing evidence that anthropogenic or "human-related" activities can significantly alter precipitation processes. Urbanization is an example of anthropogenic forcing. Recent studies continue to provide evidence that urban environments can modify or induce precipitation under a specific set of conditions.
\end{abstract}

Arid and semi-arid regions of the southwestern United States and other parts of the world are rapidly developing and placing greater demands on the environmental system. In the past fifty years, Phoenix has expanded from a predominantly agricultural center to an urbanized region with extent 700 percent larger than its size in the middle of the twentieth century. Riyadh's population grew from about a half million people in 1972 to almost two million by 2000 . Saudi Arabia experienced urbanization later than many other countries; in the early 1970s its urbanrural ratio was still about 1:3. By 1990 the ratio had reversed to about 3:1. In the mid-1970s Riyadh's population was increasing by about 10 percent a year. Irrigation also significantly increased between 1972 and 1990 southeast of Riyadh.

The study employs a 108-year precipitation historical data record, global climate observing network observations and satellite data to identify possible anomalies in rainfall in and around two major arid urban areas, Phoenix, Arizona and Riyadh, Saudi Arabia. It provides statistically sound evidence that rainfall distribution and magnitude is statistically different in post-urban Phoenix than in pre-urban (1900-1950) Phoenix. The study hypothesis that a complex interaction between the city landscape, irrigated lands, and nearby mountains have created preferred regions for rainfall development. The study also provides early evidence that rapidly urbanizing parts of the arid Middle East may also be experiencing different precipitation regimes in response to urbanization and irrigation. 